\title{
EXPLORATORY BEHAVIOR ALTERATION AS AN EPILEPTIC COMORBIDITY IN ELEVATED PLUS MAZE TEST
}

\section{PROMENE U EKSPLORATIVNOM PONAŠANJU KAO EPILEPTIČKI KOMORBIDITET U TESTU UZDIGNUTOG KRSTASTOG LAVIRINTA}

\author{
Anida Ademović ${ }^{1}$, Aleksa Leković ${ }^{1}$, Božo Knežević ${ }^{1}$, Željko Grubač $^{2}$, Nikola Šutulović ${ }^{2}$ \\ Dragan Hrnčićz , Olivera Stanojlović
}

${ }^{1}$ Faculty of Medicine, University of Belgrade, Serbia

${ }^{2}$ Laboratory for Neurophysiology, Institute for Medical Physiology 'Richard Burian', Faculty of Medicine, University of Belgrade, Serbia

Correspondence: hapuk52@gmail.com

\section{Abstract}

Keywords:

anxiety-related behavior, elevated plus maze,

lindane,

rats
Introduction: Epileptic seizure consists of preictal, ictal and postictal period. Postictal period is characterized by a variety of psychiatric phenomenon of which the most frequent ones are anxiety and depressive disorder. Anxiety in rodents can be assessed by measuring the exploratory behavior. Lindane evokes generalized tonic-clonic epileptic seizures in rats, when applied intraperitoneally, due to its lypophilic characteristics.

Aim: The aim of this study was to assess exploratory behavior linked with anxiety level in the elevated plus maze test (EPM) upon generalized seizures, induced by lindane in male rats.

Material and methods: The experiment was conducted on Wistar albino male rats that were randomly divided into: control group (DMSO, $0.5 \mathrm{ml} / \mathrm{kg}$ ) and experimental group (lindane, $8 \mathrm{mg} / \mathrm{kg}$ ) ( $\mathrm{n}=8$, each). After the drug injection, the assessment of the seizure intensity lasted for 30 minutes. Descriptive rating scale was used to describe the seizure severity. Subsequently, the EPM testing took place immediately after evoking the seizure (Test 1), after $1 \mathrm{~h}$ (Test 2) and after $24 \mathrm{~h}$ (Test 3). Time spent in open areas and number of transitions was further analyzed.

Results: Experimental group of animals spent less time in open areas of EPM, when compared to controls in Test 1 and Test 2. The same holds true for the number of transitions to the open area, i.e. lindane-treated animals tend to stay in enclosed parts of the maze in Test1, Test 2. Finally, in Test 3 there was no significant difference between the groups, in any parameter of interest.

Conclusion: Lindane-induced generalized epileptic seizures are accompanied by reduced exploratory behavior in the elevated plus maze test, up to $24 \mathrm{~h}$ after the seizure ended. This finding can be a basis for the further translational research of anxiety as epileptic comorbidity in this experimental model of epilepsy. 


\section{SAŽETAK}

Uvod. Postiktalni period karakteriše prisustvo različitih psihijatrijskih poremećaja, od kojih su najčešći anksiozni i depresivni. Eksplorativno ponašanje može da se koristi za ispitivanje stepena anksioznosti u glodara. Lindan je organohlorid, lipofilni molekul koji, primenjen intraperitonealno, može da isprovocira generalizovani toničko-klonički napad. Cilj. Cilj ove studije bio je da se proceni stepen eksplorativnog ponašanja pacova mužjaka i nivoa anksioznosti testom uzdignutog krstastog lavirinta (UKL) u postiktalnoj fazi generalizovanog epileptičkog napada izazvanog lindanom.

Materijal i metode. Eksperiment je urađen na mužjacima albino pacova Vistar (Wistar) soja, koji su nasumično podeljeni u: kontrolnu (DMSO; 0,5 ml/kg) i eksperimentalnu (lindan; $8 \mathrm{mg} / \mathrm{kg}$ ) grupu ( $\mathrm{n}=8$, po grupi). Po davanju supstanci injekcijom, 30 minuta se ocenjivao intenzitet napada korišćenjem deskriptivne skale. Test uzdignutog krstastog lavirinta je urađen odmah nakon provociranja napada (test 1), nakon 1 sata (test 2) i nakon 24 sata (test 3). Analizirano je vreme provedeno u otvorenim kracima UKL, kao i broj prelaza iz zatvorenih u otvorene krake.

Rezultati. Eksperimentalna grupa pacova provela je manje vremena u otvorenim kracima UKL testa u poređenju sa kontrolom u testu 1 i 2 . Isto važi i za broj prelaza u otvorene krake iz zatvorenih, gde pacovi tretirani lindanom pokazuju veću tendenciju ka ostajanju u zatvorenim kracima u testu 1 i 2 . Najzad, u testu 3 nije zapažena statistička značajnost

Ključne reči:

ponašanje povezano $s$ anksioznošću, test uzdignutog krstastog lavirinta,

lindan, pacovi između ispitivanih parametara, što znači da je ponašanje povezano sa anksioznošću trajalo manje od $24 \mathrm{~h}$.

Zaključak. Postiktalna faza generalizovanog epileptičkog napada indukovanog lindanom odlikuje se smanjenom tendencijom ka istraživanju nepoznate okoline u UKL testu. Opisana pojava mogla bi da posluži kao osnova za dalja translaciona istraživanja aksioznosti kao komorbiditeta epilepsije na ovom eksperimentalnom modelu generalizovanog epileptičkog napada.

\section{Introduction}

Epilepsy is a common neurological disorder, composed of epileptic seizures. There are two major types of seizure - generalized and partial (focal), depending on the part of the brain that was involved. Whether it involves a part of the brain or both hemispheres, each seizure consists of three periods: preictal, ictal and postictal period (1-3).

In more details, preictal period represents the complete ethiopathogenesis of epilepsy. The ictal period can be defined as hyperexcitability of the brain with the predominance of the excitatory neurotransmitters and the lack of the inhibitory neurotransmitters (2). This further leads to the lowering of threshold, which further results in common symptomatology (tonic-clonic movements, incontinence, parestesia, myoclonus, etc) (3).

On the other hand, postictal period is characterized by a variety of psychiatric phenomena. The major epileptic comorbidities are anxiety, depression and migraines. Moreover, it is known that depression has the most severe and long-lasting consequences and, therefore, has been in the focus of this research (3-5). Regardless, this leaves anxiety as common epileptic comorbidity under further investigation with severe effects that deserve a proper attention. Some of them include the panic attacks, social isolation, phobias, increase rate of paranoid behavior, generalized anxiety, worsening the quality of life, and finally, the increase in suicide rate (6-9).

Animal models continue to be indispensible ex- perimental tools in scrutinizing ethiopatological backgrounds of a variety of psychiatric disorders. Bearing in mind that the most sensitive way to examine the level of anxiety, in human population, is by using the psychiatric interview, in our experimental conditions we can rely merely on the alterations in behavior. The highly exploratory nature of many strains of inbred rats provides a model system for exploiting innate behavioral tendencies which appear to be released or inhibited by a variety of compounds. The theoretical basis of the anxiety or anxiolytic effects lie in a (dis)inhibition of some fearful response to a strange or aversive environment, decreasing or enhancing the natural tendency of rats to explore any new habitat $(8,9)$. Therefore, one of the signs of the anxiety-related behavior in rodents can be the alteration in the exploratory behavior. Elevated plus maze (EPM) test is among widely used tests for these purposes.

In this study, we used epileptic model induced by lindane. Lindane is an organ chlorine pesticide used in agriculture, and also in veterinary medicine. It has been discovered that it has a proconvulsive activity, evoking the generalized tonic-clonic seizures in a dose-dependent manner (10). Lindane's high lypophilic nature enables it to easily pass the blood-brain barrier, making the noticeable convulsive behavior in rodents, according to the generalization of the seizure, as well as the ictal pattern in electroencephalogram (11).

Therefore, the aim of this study was to assess male rat exploratory behavior linked with anxiety level in the EPM test after generalized seizures were induced by lindane. 


\section{Material and Methods}

Animals

The experiments were performed on 60-70 days old male Wistar albino rats (body weight 250-270 g) bred at the Military Medical Academy Breeding Laboratories, Belgrade, Serbia. All rats were kept in a sound-attenuated room under a $12 \mathrm{~h}$ light/dark cycle (starting at $8 \mathrm{am}$ ) with food and water provided ad libitum, in groups of 2-3 and in transparent, plastic cages. Animals were being acclimatized on standard and constant laboratory environment (temperature $21 \pm 2{ }^{\circ} \mathrm{C}$, relative humidity 50-60\%) for one week prior to any further experiment.

All experiment procedures were carried out in accordance with the European Council Directive and approved by Ethics Committee of the University of Belgrade.

\section{Experimental design and experimental groups}

Wistar albino male rats were randomly assigned to:

1. Control group (dimethylsulfoxide (DMSO), 0,5 ml/ $\mathrm{kg}, \mathrm{n}=8)$ and

2. Experimental group (lindane dissolved in DMSO in convulsive dose of $8 \mathrm{mg} / \mathrm{kg}, \mathrm{n}=8$ ).

Upon the drug administration, the intensity of the seizure was assessed for 30 minutes, after which the EPM test took place for the first time immediately after evoking the seizure (Test 1), as well as one hour after (Test 2) and approximately $24 \mathrm{~h}$ after (Test 3 ). Animals from both groups underwent the same procedure.

\section{Convulsive behavior assessment}

The rats placed in separate transparent, plastic cages were observed $30 \mathrm{~min}$ for the behavioral manifestations of lindane-induced motor seizures. The seizures were assessed by their incidence severity, duration and latency. Seizure intensity was determined by a modified descriptive rating scale reported by Stanojlović et al. (12) with grades defined as: grade 1 - head nodding, lower jaw twitching; grade 2 - myoclonic body jerks (hot plate reaction), bilateral forelimb clonus with full rearing (Kangaroo position); grade 3 - progression to generalized clonic convulsions followed by tonic extension of fore- and hind limbs and tail and grade 4 - prolonged severe tonic-clonic convulsions lasting over $10 \mathrm{sec}$ (status epilepticus) or frequent repeated episodes of clonic convulsions for an ex- tended period of time (over $5 \mathrm{~min}$ ). Latency to seizure was defined as a time from lindane injection to the first seizure response, and was also recorded.

\section{Elevated plus maze}

The EPM consisted of four plastic arms, arranged as a cross. More elaborately, there were two open arms, $50 \times 10 \mathrm{~cm}(\mathrm{~L} \times \mathrm{W})$, and two enclosed arms $50 \times 10 \times 40 \mathrm{~cm}$ ( $\mathrm{L} \times \mathrm{W} \times \mathrm{H})$ with an open roof. The maze was elevated to a height of $50 \mathrm{~cm}$. Each rat was put in the crossroad of two arms. Animals displaying high anxiety-like behavior tend to spend shorter amount of time in the open 'exposed' area. The time that animals spent in the enclosed and the open area was measured, as well as the number of transition to the open arms of elevated plus maze test. Each test was recorded for 5 minutes. Subsequently, the recordings were analyzed offline, by experienced observer blinded to experimental treatment.

\section{Drugs}

All drugs were of analytical purity and purchased from Sigma-Aldrich Chemical Co, U.S.A. Lindane was freshly dissolved in dimethylsulfoxide and administered intraperitoneally (i.p.) in a volume of $0.5 \mathrm{ml} / \mathrm{kg}$ rat body weight.

\section{Statistical analyses}

Results of open field test were expressed as means of \pm standard error (SE).The statistical significance of difference between control and experimental group, was estimated by $t$ test for independent samples, whereas the within-group differences were estimated by ANOVA, for repeated measurements, and with Fisher's LSD post hoc test. As a criteria for the significance of statistical differences, ${ }^{*} \mathrm{p}<0.05,{ }^{* *} \mathrm{p}<0.01$ were used.

\section{Results}

Incidence of seizures in animals in experimental group treated by lindane was $100 \%$, whereas animals in control group treated by DMSO did not show signs of convulsive behavior (incidence was $0 \%$ ). Median seizure intensity grade was $2(2 / 4)$. The other characteristics of convulsive behavior in experimental group are shown in Table 1.

Table 1. Behavioral characteristics of seizures

\section{Incidence (\%) Latency period (s) Seizure intensity}

\begin{tabular}{lccc}
\hline Experimental group & 100 & $226,5(195,5-312,5)$ & $2(1-2)$ \\
Control group & 0 & - & - \\
\hline
\end{tabular}

Focusing on the first examined parameter, time spent in the open arms of the EPM test, the statistically significant difference was noticed between experimental and control group in Test $1(\mathrm{p}<0.05$, Fig. 1$)$ and Test 2 ( $p<0.05$, Fig.1; $<<0.01$, Fig.1). The observed difference between experimental and control group in Test 3 was not statistically significant ( $p>0.05$, Fig.1). Regarding within-group variations, no significant differences were noted in the control group. On the other hand, time spent in the open arms was significantly higher in Test 3, comparing to 
Test 2 and Test $1(\mathrm{p}<0.01$, Fig.1).

The analysis of the number of entries to open arms of the EPM test showed congruent results. High statistically significant difference was observed in Test $1(\mathrm{p}<0.001$, Fig.2), as well as in Test 2 ( $\mathrm{p}<0.001$, Fig.2), between control and experimental group, in the favor of lower values in the experimental group. Finally, when it comes to Test 3, no significant difference was noticed between experimental and control group (Fig.2). No significant within-group variations were noted in the control, as well as in the experimental group ( $>00.05$, Fig.2).

Animals were randomly assigned in control (DMSO, $0.5 \mathrm{ml} / \mathrm{kg}$, i.p., $\mathrm{n}=8$ ) and experimental (lindane, $8 \mathrm{mg} / \mathrm{kg}$, i.p., $\mathrm{n}=8$ ) group.
Characteristics of convulsive seizures: incidence (percentage of rats, which had convulsive reaction in regards to the total number of rats in a group), latency period (the time elapsed of administering lindane until the first convulsive reaction) and the intensity of seizure (assessed based on a descriptive scale with graduses 0-4) were recorded during $30 \mathrm{~min}$.

Values of the latency period(s) and intensity of seizure (gradus) are expressed with median and interquartile range. convulsions.

In control group there were no signs of

Figure 1. Time spent in opened arms of the elevated plus maze test (EPM)

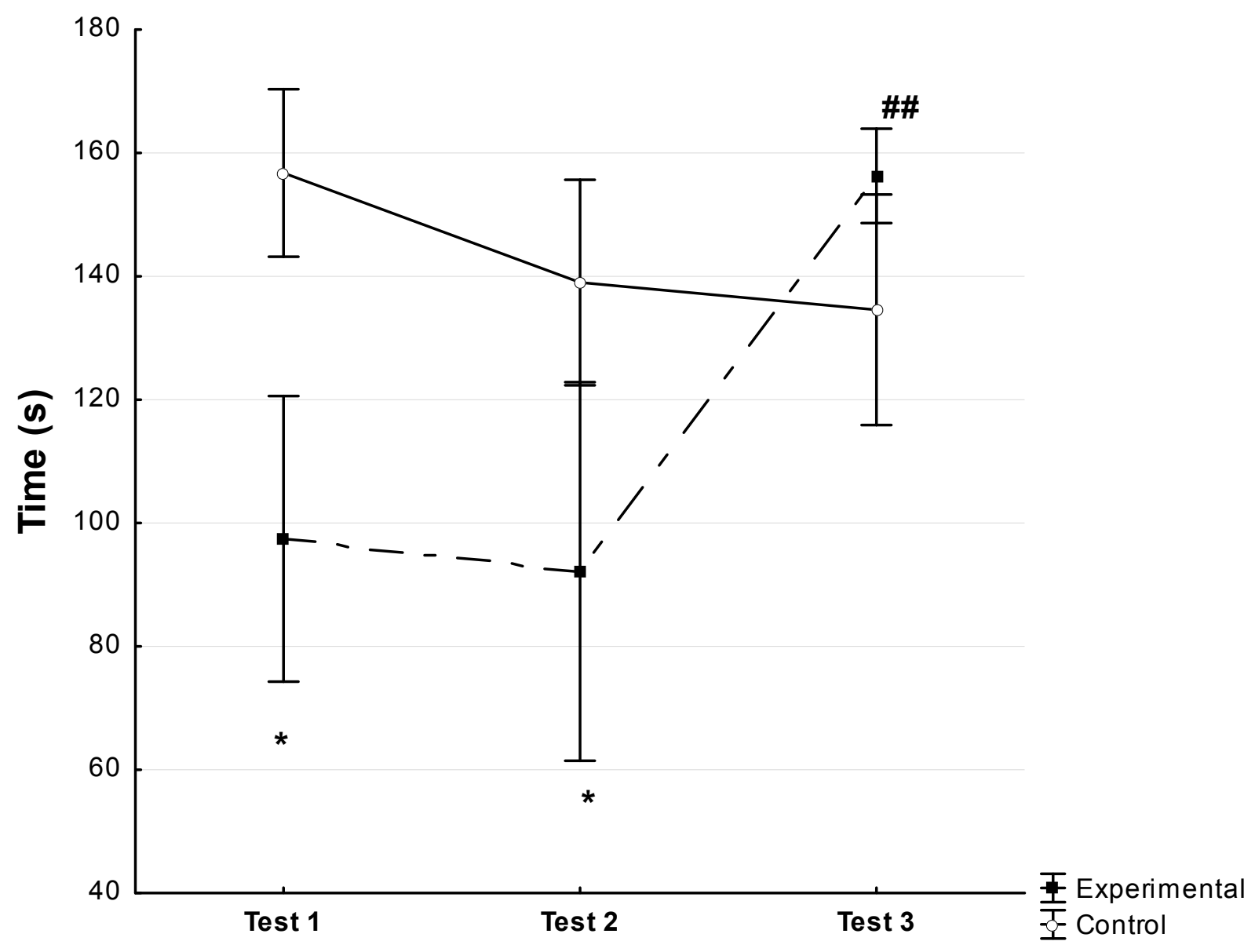

Time spent in opened arms of the elevated plus maze test was measured immediately after evoking the seizure (Test 1), $1 \mathrm{~h}$ (Test 2) and 24h upon the seizure onset (Test 3). Control group underwent the same procedure.

Data are expressed as means \pm standard error (SE). Statistical significance of difference in the amount of time rats spent in an enclosed arms of the elevated plus maze test (EPM) between control and experimental group was estimated by $t$ test for independent samples $\left({ }^{*} p<0.05\right)$, whereas the within-group differences were estimated by ANOVA for repeated measurements with Fisher's LSD post hoc test using the ANOVA for repeated measurements with Fisher's LSD post hoc test (\#\# $\mathrm{p}<0.01$ ).

For details see the caption to Table 1.
Number of entries to open arms of the elevated plus maze test was measured immediately after evoking the seizure (Test 1), $1 \mathrm{~h}$ (Test 2) and $24 \mathrm{~h}$ upon the seizure onset (Test 3). Control group underwent the same procedure.

Data are expressed as means \pm standard error (SE). Statistical significance of difference in number of entries to open arms of elevated plus maze test (EPM) between control and experimental group was estimated by using the $t$ test for independent samples $\left({ }^{* * *} \mathrm{p}<0.001\right)$, whereas the within-group differences were estimated by ANOVA for repeated measurements with Fisher's LSD post hoc test using the ANOVA for repeated measurements with Fisher's LSD post hoc test.

For details see the caption to Table $\mathbf{1}$. 
Figure 2. Number of entries to open arms of the elevated plus maze test (EPM)

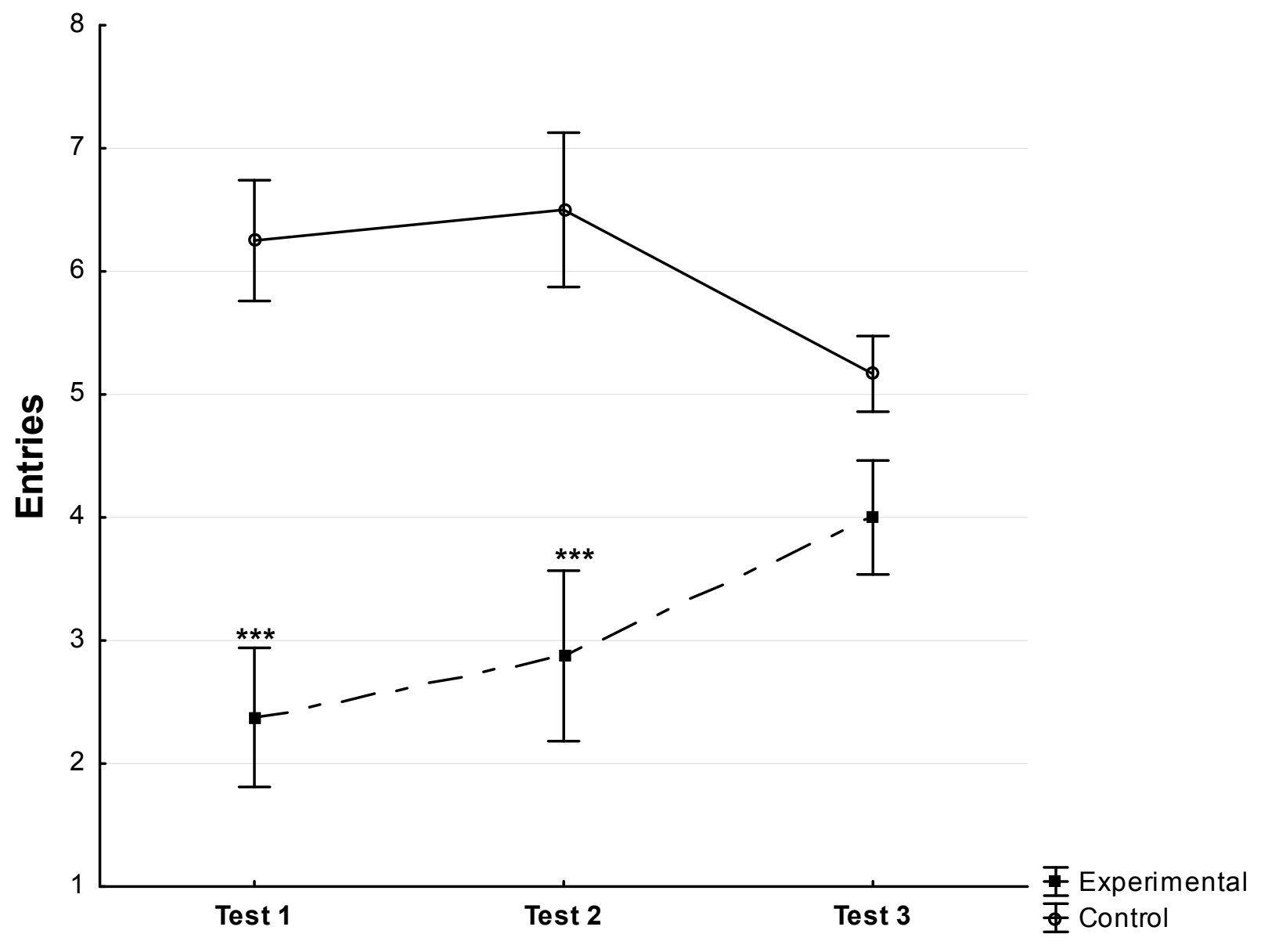

\section{Discussion}

The altered behavioral pattern of rats was observed in experimental groups, when compared to the controls. Lindane-treated rats showed significant decrease in time spent in open arms of the EPM test (Fig.1) and had less number of entries to them, as well. (Fig.2)

As nocturnal animals, rats have tendency to stay in the dark areas and corners, but also have innate propensity to explore the new environment. Therefore, previously stated results can be understood as the evidence of the anxiety-related behavior and cannot be biased as any other motor impairment of mobility.

The exploratory drive of rats from experimental group (i.e. seizure ones), which was diminished during the first two tests, markedly recovered after 24 hours during the third testing. This fact could be explained as temporal dimension of the postictal exploratory drive alterations.

From the previously published data, it can be assumed that epilepsy induces significant, but heterogeneous, effects in animals. Many studies have been using different models for inducing epilepsy in experimental animals, in order to examine correlation between epilepsy and its comorbidities. Interestingly, no matter if the experimental animals were being genetically prone to the epileptic seizures (13), or if the bilateral or unilateral kindling, the decreased levels of exploration were always noticed, as a method in inducing the seizures were used
(14), further leading to the possible conclusion of the presence of anxiety-related behavior (15). On the other hand, the decrease of the exploration-prone behavioral pattern of rats, differs from one study to another. The majority of studies drew the conclusion that it lasted for approximately $12-24 \mathrm{~h}$. The possible explanation can be based on the correlation between seizure intensity and duration. The results from our study do not significantly deviate from these findings, meaning that this model is suitable for the further research of this phenomenon $(8,13-15)$.

However, some studies also drew different conclusion to ours. For example, the study that used pentylenetetrazol for evoking rats seizures (16), proposed that this may be due to the side effects of this drug. This can be further explained by the decrease in serotoninergic neurotransmission in the hippocampus and prefrontal cortex, which stands for the major regulatory stations, regarding the exploratory behavior. Concerning the traumatic epileptic seizure, the underlying mechanism of the decrease in exploratory activity, can be the trauma of the amygdaloidal body (17-20).

The crucial structure in controlling the exploratory behavior is the amygdaloidal body. Moreover, it has been proven that epilepsy triggers the atrophy of amygdale on the same side of the seizure, leading to the disruption in controlling the behavior and emotions $(21,22)$. In the core of the pathophysiological understanding of the epileptic seizure and its comorbidities lies the disbalance of 
the neurotransmitters. The most commonly considered are the serotoninergic and noradrenergic neurotransmitter systems, which are significantly increased. On the other hand, gamma-aminobutyric acid (GABA), as the representative of the inhibitory neurotransmitters, is decreased $(20,23)$. These disbalances further lead to the lowering of the threshold and induction of discharge. Alterations in neurotransmission balance affects mainly limbic structures, locus caeruleus and colliculi $(21,23)$.

Lindane has a dimorphic impact on the central nervous system. It acts primarily by enhancing release of excitatory transmitters from the presynaptic terminal, making a sufficient excitation, $(8,11)$. Inhibiting GABA and decreasing the levels of other inhibitory neurotransmitters, lindane lowers the seizure threshold $(7,8,24,25)$. Nevertheless, lindane's toxic effects may also lead to a neuronal dysfunction, which can be reflected as behavior alterations $(24,25)$.

\section{Reference}

1. Fisher R, Emde Boas W, Blume W. et al. Epileptic Seizures and Epilepsy: Definitions Proposed by the International League Against Epilepsy (ILAE) and the International Bureau for Epilepsy (IBE). Epilepsia. 2005; 46(4):470-472.

2. Gloor P, Fariello G. Generalized epilepsy: some of its cellular mechanisms differ from those of focal epilepsy. Trends in Neurosciences. 1988; 11:63-68.

3. Blume WT, Luders HO, Mizrahi E, et al. Glossary of descriptive terminology for ictal semiology: report of the ILAE Task Force on Classification and Terminology. Epilepsia 2001;42:1212-8.

4. Tellez-Zenteno J.F., Patten S.B., Jetté N., Williams J., Wiebe S. Psychiatric comorbidity in epilepsy: A population-based analysis. Epilepsia.2007;48:2336-2344.

5. Andreas M. Kanner MD. Anxiety disorder in Epilepsy: the forgotten psychiatric comorbidity. Epilepsy Curr. 2011;11(3),90-91

6. Choi-Kwon S., Chung C., Kim H., Lee S., Yoon S., Kho H., Oh J., Lee J. Factors affecting the quality of life in patients with epilepsy in Seoul, South Korea. ActaNeurologicaScandinavica.2003;108:428.

7. Beyenburg S, Mitchell A, Schmidt D, Elger C, Reuber M. Anxiety in patients with epilepsy: Systematic review and suggestions for clinical management. Epilepsy \& Behavior. 2005;7(2):161-171;

8. Shaw FZ, Chuang SH, Shieh KR, Wang YJ. Depression- and anxiety-like behaviors of a rat model with absence epileptic discharges. Neuroscience Elsevier.2009; 160:382-393.

9. Goldstein MA, Harden CL. Epilepsy and Anxiety. Epilepsy \& Behavior.2000; 1(4):228-234.

10. Vucevic D, Hrncic D, Radosavljevic T, et al. Correlation between electrocorticographic and motor phenomena in lindane-induced experimental epilepsy in rats. Can J Physiol Pharmacl.2008;86(4):173-9.

11. Hrncic D, Rasic-Markovic A, Djuric D, Susic V, Stanojlovic $\mathrm{O}$. The role of nitric oxide in convulsions induced by lindane in rats.Food ChemToxicol. 2011,49(4):947-954.

12. Olivera Stanojlović, Aleksandra Rašić-Marković, DraganHrnčić, VeselinkaŠušić, DjuroMacut, TatjanaRadosavljević, DraganDjuricTwo Types of Seizures in Homocysteine Thiolactone-Treated Adult Rats, Behavioral and Elec-

\section{Conclusion}

Results of our study show that rats treated with lindane developed generalized epileptic seizures. Postictal period was accompanied by reduced exploratory behavior tested in the EPM test. This finding can be a basis for the further translational research of anxiety as epileptic comorbidity. We believe that further studies on this, aa well as other models, will allow better understanding of the mechanisms of behavioral and mood alterations upon seizures in human.

\section{Acknowledgment}

This work was supported by the Ministry of Education, Science and Technological Development of Serbia (grant \#175032).

troencephalographic Study. Cell and Molecular Neurobiol. 2009;29(3):329-339.

13. Jones N., Salzberg M., Kumar G., Couper A, Morris M, O'Brien T. Elevated anxiety and depressive-like behavior in a rat model of genetic generalized epilepsy suggesting common causation. Experimental Neurology 2008, 209:254260.

14. Nieminen Sakari, Sirvio Jouni, Teittinen Kalevi, et al. Amygdala Kindling Increased Fear-Response, but did not impair spatial memory in rats Physiology \& Behavior 1991; 51:845-849.

15. Caldecott-Hazard S. Interictal changes in behavior and cerebral metabolism in the rat: opioid involvement. Experimental neurology 1988; 99:73-83.

16. Szyndler J, Rok P, Maciejak et al. Effects of pentylenetetrazol-induced kindling of seizures on rat emotional behavior and brain monoaminergic systems. Pharmacology, biochemistry and behavior 2002.73:851-861.

17. Brady JV, Schreiner L, Geller I, Kling A. Subcortical mechanisms in emotional behavior: the effect of rhinencephalic injury upon the acquisition and retention of a conditioned avoidance response in cats. J. Comp. Physiol. Psychol. 1954;47: 179-186.

18. Pariente PD, Lepine JP, Lellouch J. Lifetime history of panic attacks and epilepsy: an association from a general population survey. J Clin Psychiatry. 1991;52:88-89.

19. Issacs KL, Philbeck JW, Barr WB, Devinsky O, Alper K. Obsessive-compulsive symptoms in patients with temporal lobe epilepsy EpilepsyBehav. 2004;5:569-574

20. Fisher R, Schachter S. The Postictal State: A Neglected Entity in the Management of Epilepsy. Epilepsy \& Behavior 2000; 1:52-59.

21. Satishchandra P,Krishnamoorthy ES, Elst van LT, et al. Medial temporal structures and comorbid anxiety in refractory partial epilepsy. J Neuropsychiatry Clin Neurosci.2003; 15:450-452.

22. Cendes F, Andermann F, Gloor P,etal.Relationship between atrophy of the amygdala and ictal fear in temporal lobe epilepsy. Brain.1994; 117:739-746.

23. Carrey W. Current Clinical Medicine.Philadelphia, PA : Saunders/Elsevier, 2009. 
Ademović A. et al. Exploratory behaviour alteration as an epileptic comorbidity in elevated plus maze test. MedPodml 2017, 68(3):22-28

24. Klein R. Anxiety disorders. The journal of psychology and psychiatry 2009; 50:1-2.

25. Jones J, Fitzpatrick J, Rogers V. Psychiatric-Mental Health nursing: An interpersonal approach. Springer Publishing company 2002. 